\title{
AN EXPERIMENTAL STUDY ON SELF CURING CONCRETE
}

TatineniYeswanth Sai ${ }^{1}$ and Muvvala Sambasiva $\mathrm{Rao}^{2}$

Abstract-Concrete is a mixture of cement, aggregates and water with or without admixtures. To attain desirable strength and other properties, curing is necessary. Curing is the process of maintaining the proper moisture content to promote optimum cement hydration immediately after placement. The main objective of this experimental investigation is to find out behavior of self-curing concrete. The experiments are designed by adding a shrinkage admixture(POLYETHYLENE GLYCOL-400)at different percentages such as $0 \%, 0.5 \%, 1 \%, 1.5 \%, 2 \%$ of cement content . The specimens are cured without water for 28 days and later different strength characteristics such as compressive strength, tensile strength are studied.

\section{ADVANTAGES OF INTERNAL CURING}

- Internal curing is a method to provide the water to hydrate all the cement, accomplishing what the mixing water alone cannot do.

- Provides water to keep the relative humidity $(\mathrm{RH})$ high, keeping self-desiccation from curing.

- Eliminates largely autogenous shrinkage.

- Maintains the strengths of mortar/concrete at the early age (12 to $72 \mathrm{hrs}$.) above the level where internally\& externally induced strains can cause cracking

- Can make up for some of the deficiencies of external \& internal curing, both human related (critical period when curing is required in the first 12 to 72 hours) and hydration.

\section{MATERIALS REQUIRED AND ITS PROPERTIES}

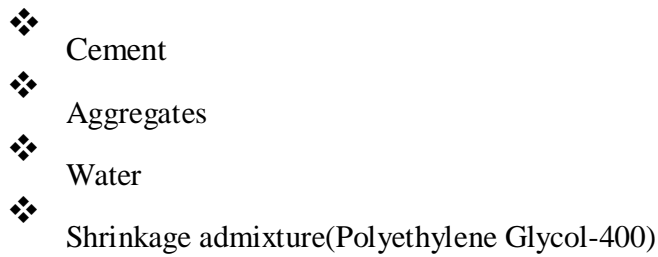

PROPERTIES OF POLY ETHYLENE GLYCOL-400

\begin{tabular}{|l|l|l|}
\hline S.NO & PROPERTIES & VALUES \\
\hline 1 & Molecular weight & 400 \\
\hline 2 & Appearance & Clear liquid \\
\hline 3 & Specific gravity & 2.25 \\
\hline 4 & pH & $5-7$ \\
\hline
\end{tabular}

\footnotetext{
${ }^{1}$ (MES-AUSTRALIA) Old Office Address: Civil Department, Sri Vasavi Engineering College, Pedatadepalli, Tadepalligudem, West Godavari District, Andhra Pradesh, India - 534101

${ }^{2}$ Civil Department, Sri Vasavi Engineering College, Pedatadepalli, Tadepalligudem, West Godavari District, Andhra Pradesh, India - 534101
} 


\begin{tabular}{|l|l|l|}
\hline 5 & Density & $1.128 \mathrm{~g} / \mathrm{cm}^{3}$ \\
\hline 6 & Melting point & 4 to $88^{0} \mathrm{c}$ \\
\hline
\end{tabular}

\section{CONCRETE MIX DESIGN}

\section{Mix design for “M30”'Grade}

(a) Stipulations for Proportioning:

1. Grade designation

2. Type of cement

3. Type of admixture

4. Maximum nominal size of aggregate

5. Minimum cement content

6. Maximum water-cement ratio

7. Workability

8. Exposure condition

9. Method of concrete placing

10. Degree of supervision

11. Type of aggregate

12. Maximum cement $(\mathrm{OPC})$ content
M30

OPC53gradeconforming to IS 8112

Polyethylene glycol-400

$20 \mathrm{~mm}$

$320 \mathrm{~kg} / \mathrm{m} 3$

0.45

$100 \mathrm{~mm}$ (slump)

Severe (For plain Concrete)

Hand placing

Good

Sub angular aggregate

$414.58 \mathrm{~kg} / \mathrm{m} 3$

(b) Test Data for Materials:

1. Cement used

2. Specific gravity of cement

3. Specific gravity of coarse aggregate

4. Specific gravity of fine aggregate

5. Water absorption

Coarse aggregate

Fine aggregate

6. Free (surface) moisture

Coarse aggregate

Fine aggregate
MAHA OPC 53grade

3.10

2.85

2.68

$0.5 \%$

$1.0 \%$

Nil

Nil

7. Sieve analysis

Coarse aggregate

Fine aggregate

Nominal max Size of aggregate $20 \mathrm{~mm}$ as per IS 383 Confirming to grading Zone-III of table 4 of IS383 
(c) Target Strength for Mix Proportioning

'

$+1.65 \mathrm{~S}$

Where,

' = Target average compressive strength at 28 days,

$\mathrm{F}_{\mathrm{ck}}{ }^{\prime}=$ Characteristics compressive strength at 28 days,

And $\quad \mathrm{S}=$ Standard deviation.

From Table I, Standard Deviations $=5$

Therefore, target strength $=30+1.65$

$$
/ \quad=2 .
$$

(d) Selection of Water-Cement Ratio:

From Table 5 of IS 456, maximum water-cement ratio (see Note under 4.1) $=0.45$.

Based on experience, adopt water-cement ratio as 0.45 .

Hence, Ok.

(e) Selection of Water Content:

From Table 2, maximum water content

For $20 \mathrm{~mm}$ aggregate $=186$ liter (for 25 to $50 \mathrm{~mm}$ slump range $)$

Sub angular aggregates $=186-10=176$ liter

Estimated water content for $75 \mathrm{~mm}$ slump $=176+\left(100^{6}\right) \times 176$

$=186.56$ liter

\section{(f) Calculation of Cement:}

Water-cement ratio $=0.45$

Cement content $=186.56=414.58 \mathrm{~kg} / \mathrm{m}^{3}$

0.45

From Table 5 of IS 456 , minimum cement content for 'Severe' exposure conditions $=320 \mathrm{~kg} / \mathrm{m}^{3}$

$414.58 \mathrm{~kg} / \mathrm{m}^{3}>320 \mathrm{~kg} / \mathrm{m}^{3}$

Hence, ok.

(g) Proportion of volume of coarse aggregate fine aggregate content: (Zone III)

From Table 3, volume of coarse aggregate corresponding to $20 \mathrm{~mm}$ size aggregate and fine aggregate

For water-cement ratio of $0.45=0.65$

Volume of fine aggregate content $=1-0.65=0.35$

\section{(h) Mix Calculations:}

The mix calculations per unit volume of concrete shall be as follows: 

a) Volume of concrete
$=\quad 1 \mathrm{~m}^{3}$
b) Volume of cement
$=$
$\frac{\text { mass of cement }}{\text { Specific gravity of cement }}$
X $1 / 1000$
c)

$$
=0.134 \mathrm{~m}^{3}
$$
d) Volume of water
e)
$\frac{\text { mass of water }}{\text { Specific gravity of water }}$
X $1 / 1000$
$=0.187 \mathrm{~m}^{3}$
f) Volume of all in aggregate =$$
=\quad \mathrm{a}-(\mathrm{b}+\mathrm{c})
$$$$
=\quad 1-(0.134+0.187)
$$$$
=0.679 \mathrm{~m}^{3}
$$
g) Mass of coarse aggregate $\quad=\quad \mathrm{dX}$ Volume of coarse aggregate
$\mathrm{X}$ Specific gravity of coarse aggregateX 1000
$=\quad 0.679 \times 0.65 \times 2.85 \times 1000$
$=\quad 1257.85 \mathrm{Kg}$
h) Mass of fine aggregate $\quad=\quad \mathrm{dX}$ Volume of coarse aggregate
$\mathrm{X}$ Specific gravity of coarse aggregate
X 1000
$=\quad 0.679 \times 0.35 \times 2.69 \times 1000 \mathrm{x}$
$=\quad 639.28 \mathrm{Kg}$

Material required for $\mathrm{M30}$ grade concrete per one cubic meter quantity:

$\begin{array}{lllcll}\text { Material } & \text { Water } & \text { Cement } & \text { Fine aggregate } & \text { coarse aggregate } \\ \mathbf{K g} / \mathbf{m}^{\mathbf{3}} & 186.56 & 414.58 & 639.28 & 1257.85 \\ \text { Ratio } & 0.45: & 1 & : & 1.54 & :\end{array}$

\section{Quantities of Each Mould in kg:}

Mix proportions of M30 grade: 1: 1.54: 3.04

Water cement ratio $=0.45$

Air content $=2 \%$

Specific gravity of cement $\mathrm{sc}=3.10$

Specific gravity of fine aggregate $=2.68$

Specific gravity of coarse aggregate $=2.85$

$\mathrm{V}=$ volume of each cube $=0.15 \times 0.15 \times 0.15=3.375 \times 10^{-3} \mathrm{~m}^{3}$

$\mathrm{V}=$ volume of each cylinder $=0.15 \times 0.15 \times 0.3 \times 4=5.3 \times 10^{-3} \mathrm{~m}^{3}$

\section{For cubes:}


Cement $=1.39 \mathrm{~kg}$

Fine aggregate $=2.15 \mathrm{~kg}$

Coarse aggregates $=4.24 \mathrm{~kg}$

Water $=0.63$ liter

\section{For cylinders:}

Cement $=2.19 \mathrm{~kg}$

Fine aggregate $=3.38 \mathrm{~kg}$

Coarse aggregates $=6.67 \mathrm{~kg}$

Water $=0.99$ liter

Quantities of addition of PEG-400 to concrete mix:

PEG-400 is the shrinkage admixture which givesmorestrength when those are added to the concrete than the normal concrete mix. PEG-400 is added to the concrete mix in the proportions of $0.5,1.0,1.5,2.0$ percentages of the weight of cement.

\section{Addition of PEG-400 in Proportions to the Concrete Mix}

\begin{tabular}{|l|l|l|l|}
\hline $\begin{array}{l}\text { Percentage of PEG-400 } \\
\text { (In cement content) }\end{array}$ & $\begin{array}{l}\text { Weight of cement } \\
\text { content (gram) }\end{array}$ & $\begin{array}{l}\text { Weight of PEG-400 } \\
\text { (gram) }\end{array}$ & $\begin{array}{l}\text { PEG-400 } \\
\text { (Liter) }\end{array}$ \\
\hline 0.5 & 414580 & 2072.9 & 1563.27 \\
\hline 1.0 & 414580 & 4145.8 & 3126.54 \\
\hline 1.5 & 414580 & 6218.7 & 4689.8 \\
\hline 2.0 & 414580 & 8291.6 & 6253.09 \\
\hline
\end{tabular}

RESULTS AND DISCUSSIONS

\section{COMPRESSIVE STRENGTH VALUES FOR SELF CURING CONCRETE BY USING PEG-400}

Cubes:

7-Days compressive strength results

\begin{tabular}{|l|l|l|}
\hline S.NO & $\begin{array}{l}\text { Adding of PEG-400 in percentage weight of } \\
\text { cement }\end{array}$ & $\begin{array}{l}\text { Compressive strength } \\
\text { (MPa) }\end{array}$ \\
\hline 1 & 0 & 22.07 \\
\hline 2 & 0.5 & 24.44 \\
\hline
\end{tabular}




\begin{tabular}{|l|l|l|}
3 & 1.0 & 25.04 \\
\hline 4 & 1.5 & 25.63 \\
\hline 5 & 2.0 & 23.41 \\
\hline
\end{tabular}

28-Days compressive strength results

\begin{tabular}{|l|l|l|}
\hline S.NO & $\begin{array}{l}\text { Adding of PEG-400 in percentage } \\
\text { weight of cement }\end{array}$ & $\begin{array}{l}\text { Compressive } \\
\text { Strength (MPa) }\end{array}$ \\
\hline 1 & 0 & 30.07 \\
\hline 2 & 0.5 & 32.30 \\
\hline 3 & 1.0 & 32.82 \\
\hline 4 & 1.5 & 33.63 \\
\hline 5 & 2.0 & 31.7 \\
\hline
\end{tabular}

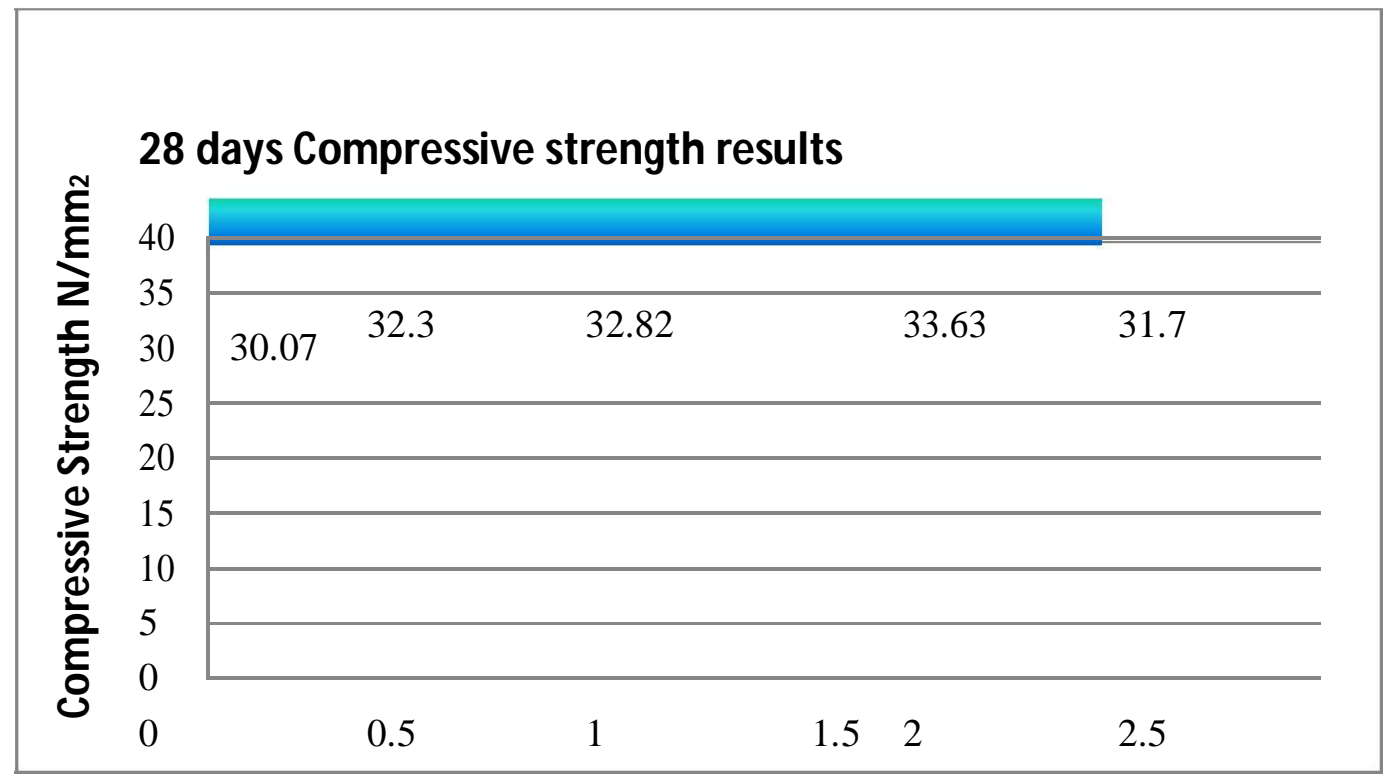

$\%$ of PEG-400 
Compressive strength results for self-curing concrete by using PEG-400

\begin{tabular}{|l|l|l|l|}
\hline S.NO & $\begin{array}{l}\text { Adding of PEG-400 in percentage } \\
\text { weight of cement }\end{array}$ & 7 Days & 28 Days \\
\hline 1 & 0 & 22.07 & 30.07 \\
\hline 2 & 0.5 & 24.44 & 32.30 \\
\hline 3 & 1.0 & 25.04 & 32.82 \\
\hline 4 & 1.5 & 25.63 & 33.63 \\
\hline 5 & 2.0 & 23.41 & 31.7 \\
\hline
\end{tabular}

Compressive strength results for 7 days and 28 days

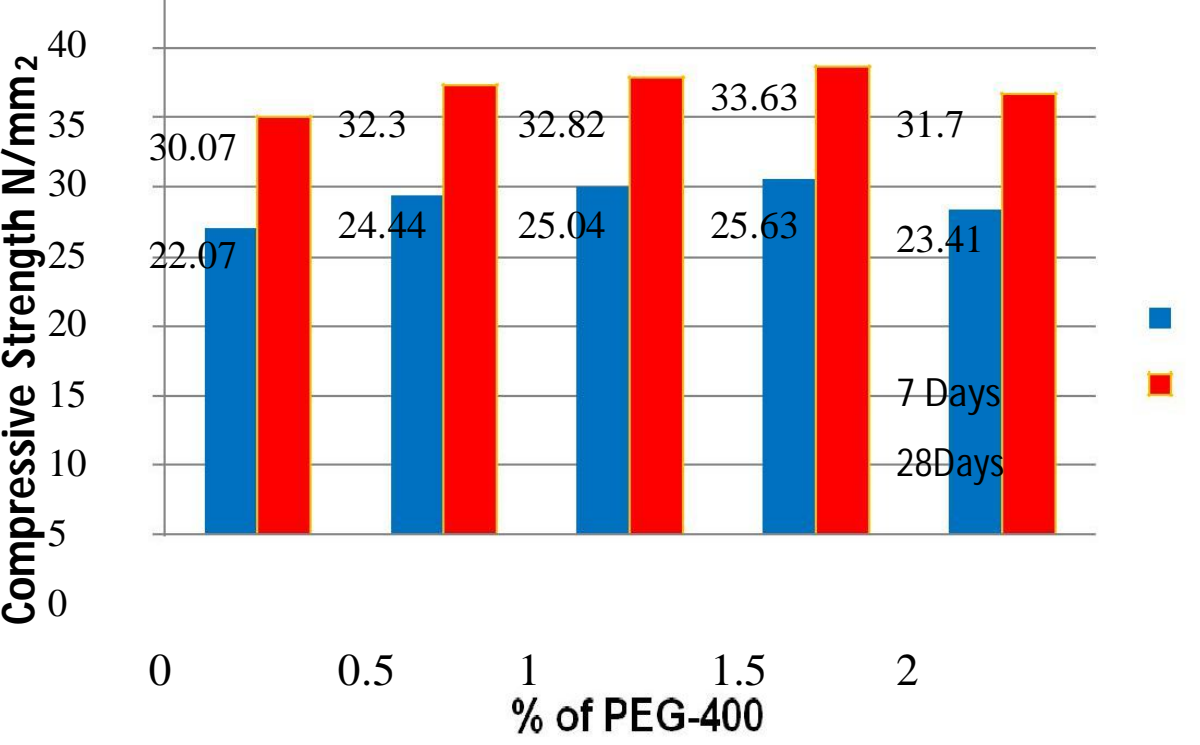




\section{Cylinders:}

7-Days Tensile strength results

\begin{tabular}{|l|l|l|}
\hline S.NO & $\begin{array}{l}\text { Adding of PEG-400 in percentage } \\
\text { weight of cement }\end{array}$ & $\begin{array}{l}\text { Compressive } \\
\text { Strength (MPa) }\end{array}$ \\
\hline 1 & 0 & 2.26 \\
\hline 2 & 0.5 & 2.36 \\
\hline 3 & 1.0 & 2.64 \\
\hline 4 & 1.5 & 2.88 \\
\hline 5 & 2.0 & 2.59 \\
\hline
\end{tabular}

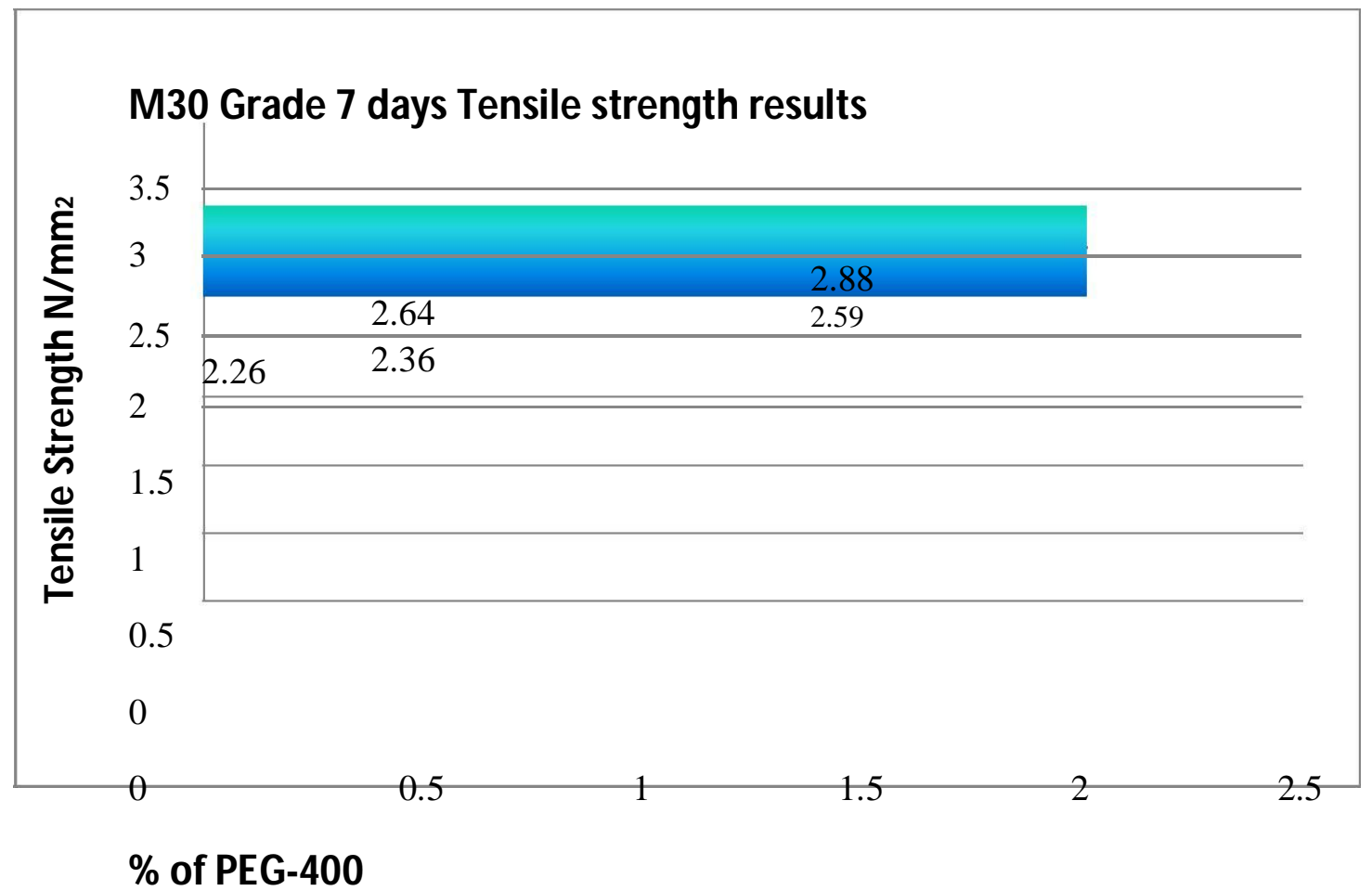


28-Days Tensile strength results

\begin{tabular}{|l|l|l|}
\hline S.NO & $\begin{array}{l}\text { Adding of PEG-400 in percentage weight } \\
\text { of cement }\end{array}$ & $\begin{array}{l}\text { Compressive } \\
\text { Strength (MPa) }\end{array}$ \\
\hline 1 & 0 & 2.36 \\
\hline 2 & 0.5 & 2.45 \\
\hline 3 & 1.0 & 2.74 \\
\hline 4 & 1.5 & 2.97 \\
\hline 5 & 2.0 & 2.36 \\
\hline
\end{tabular}

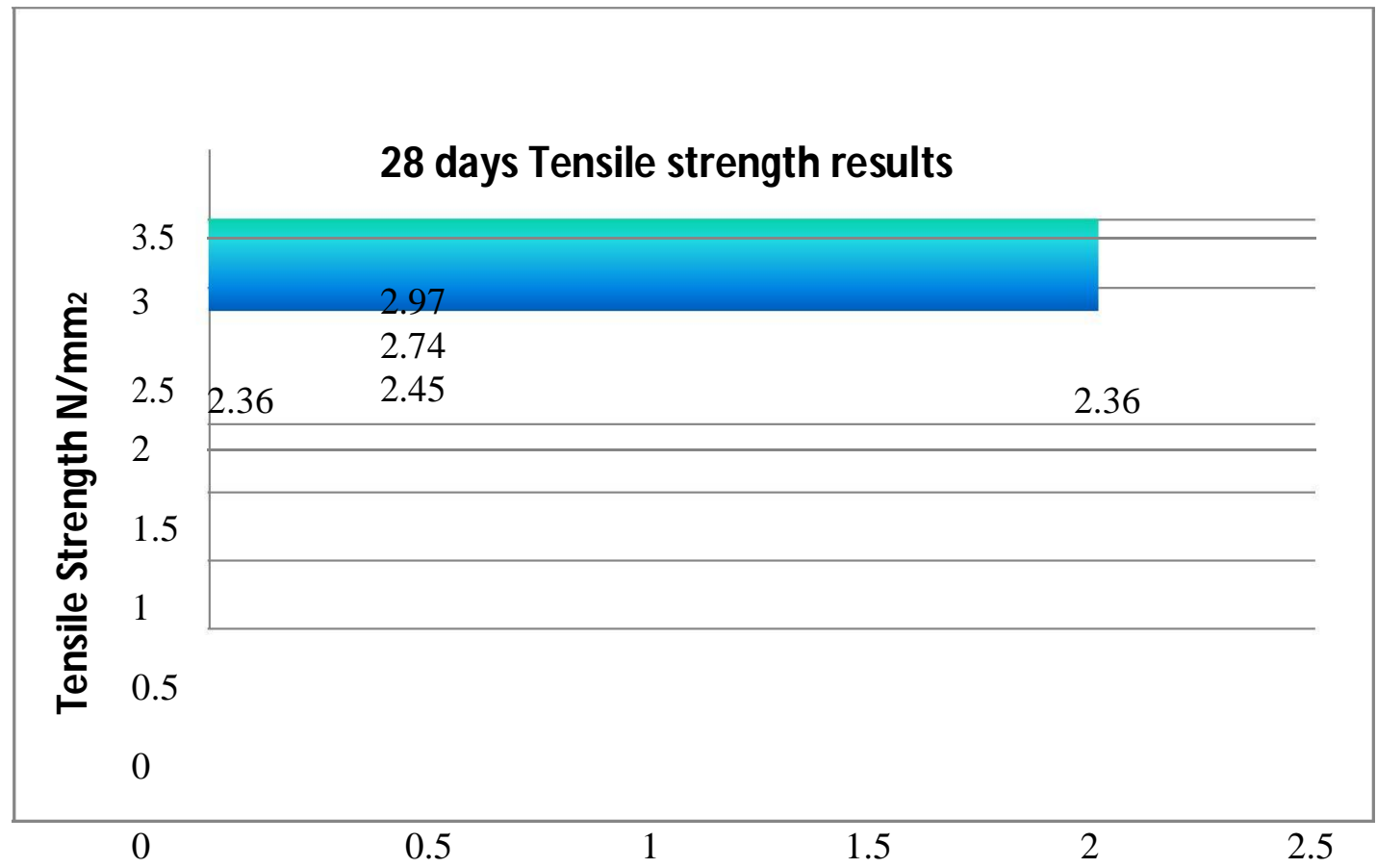

$\%$ of PEG-400 
Tensile strength results for self-curing concrete by using PEG-400

\begin{tabular}{|l|l|l|l|}
\hline S.NO & $\begin{array}{l}\text { Adding of PEG-400 in percentage } \\
\text { weight of cement }\end{array}$ & 7 Days & 28 Days \\
\hline 1 & 0 & 2.26 & 2.36 \\
\hline 2 & 0.5 & 2.36 & 2.45 \\
\hline 3 & 1.0 & 2.64 & 2.74 \\
\hline 4 & 1.5 & 2.88 & 2.97 \\
\hline 5 & 2.0 & 2.59 & 2.36 \\
\hline
\end{tabular}

Tensile strength results for 7 days and 28 days

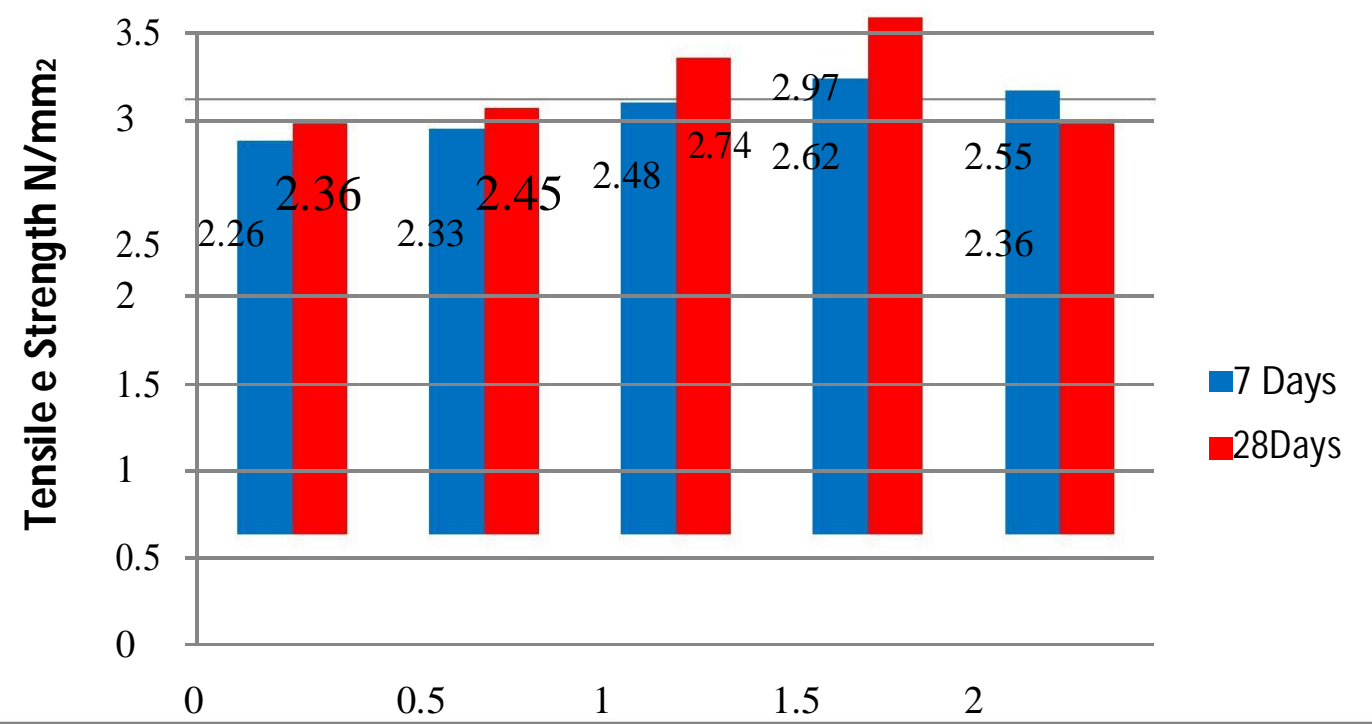

$\%$ of PEG-400 


\section{CONCLUSIONS}

From the above study we conclude that the compressive strength of the concrete cubes has gradually increased up to adding admixture of $1.5 \%$ of cement by PEG- 400 .

Compared to compressive strength of $0.5 \%, 1.0 \%$ and $1.5 \%$ adding admixture of cement by PEG-400, the compressive strength of $2.0 \%$ PEG-400 concrete has been decreased.

Whereas comparing to traditional concrete, compressive strength of concrete has been increased by adding $1.5 \%$ of cement by PEG-400.

Hence for economical view $2.0 \%$ adding admixture is preferable and in the perspective of compressive strength $1.5 \%$ adding is suggested.

The gain in compressive strength is improved depending upon the adding admixture level of PEG-400 in weight of cement.

The shrinkage admixture (PEG-400) inclusion generally improves tensile strength, compressive strength and also increases the service life of concrete structures.

\section{REFERENCES}

[1]. Shetty M.S., Concrete Technology Theory and Practice $3^{\text {rd }}$ Edition, S.Chand Company Limited, New Delhi-1991.

[2]. IS: 10262-1982 \& 2009 recommended guide lines for concrete mix design, Indian Standard Institution, New Delhi.

[3]. IS: 456-2000 design and drawing of concrete structures code book should be used.

[4]. IS: 383-1970., specifications for coarse and fine aggregates from natural sources for concrete, Bureau of Indian standards, and New Delhi, India.

[5]. IS: 516-1959., Indian standard code of practice for methods of tests for strength concrete, Bureau of Indian standards, New Delhi, India.

[6]. $\quad$ IS 7869 (Part-II)., Indian Standard Specifications for admixtures for concrete, 1981.

[7]. Krishnan Raju.Design of concrete mix $4^{\text {th }}$ Edition, C.B.S. Publishers and Distributors.

[8]. M.S. Ravi Kumar, Selvamony C.S.U. Kannan and Basil Gnanappa., Behavior of self-compactedselfcuring kiln ash concrete various admixtures, Sathyabama University, Chennai, India Moderator Gnanadhasan polytechnic, and Nagercoil, India.

[9]. Dale P. Bentz, Pietro Lura, John W.Roberts., mixture properties for internal curing, The University of Wiscons-Milwaukee, International Concrete, February 2005.

[10]. Research papers on shrinkage admixture in self-curing concrete have been used. 